\title{
Evidence for a Mucosal Effect of Aldosterone on Sodium Transport in the Toad Bladder*
}

\author{
Geoffrey W. G. Sharp,† Cecil H. Coggins, $\$$ Norman S. Lichtenstein,§ and \\ Alexander Leaf \\ (From the Departments of Medicine, Massachusetts General Hospital and the Harvard \\ Medical School, Boston, Mass.)
}

Evidence has been presented suggesting that the means by which aldosterone causes a stimulation of sodium transport across the isolated toad bladder is to increase the entry of sodium into the transport pool of the mucosal cells across their apical surface. Thus radioactive sodium added to the mucosal bathing medium was found in higher concentrations in bladders exposed to aldosterone than in paired control tissues. A higher rate of transepithelial transport induced by aldosterone, together with a higher content of the transported sodium in the tissue, is consistent with an effect of the hormone to increase the permeability of the apical surface rather than the basal surface of the mucosal layer of cells (1) in an epithelium possessing these two major permeability barriers $(2,3)$.

This type of experiment, however, is open to several criticisms. First, the effect, although it occurred in every experiment and was statistically significant, was small with aldosterone. Second, one does not know where in the tissue the extra radioactive sodium may be. Although the submucosa and serosa in this tissue have been found to have a high permeability to ions $(4,5)$, this does not provide absolute assurance that the extra

* Submitted for publication April 11, 1966; accepted July 13, 1966.

This investigation was supported in part by a grant from the John A. Hartford Foundation and by U. S. Public Health Service research grants HE-06664 from the National Heart Institute and AM-04501 from the National Institute of Arthritis and Metabolic Diseases.

† Address requests for reprints to Dr. Geoffrey W. G. Sharp, Cardiorenal Unit, Massachusetts General Hospital, Boston, Mass. 02114.

¥Advanced Research Fellow of the American Heart Association during the period of this study.

$\S$ Present address: National Cancer Institute, Bldg. 10-6N 119, National Institutes of Health, Bethesda, Md. 20014. radioactive sodium may not be trapped in connective tissue or smooth muscle rather than lie between the two limiting permeability barriers of the mucosal cells, as necessary for the valid interpretation of this test. Furthermore, electron microscopy reveals intercellular lakes between the lateral and basal portions of adjoining cells in the mucosal layer of cells (6). Again we have no assurance that the excess radioactivity is not trapped within such lakes after already crossing the two permeability barriers.

Because of the uncertainties with the above approach, the problem of how aldosterone induces an increased transport of sodium has been further examined. Two lines of evidence have been brought to bear on this point: 1) The metabolic effects of aldosterone on the utilization of pyruvate and acetoacetate were examined to determine whether the stimulation by the hormone of their utilization was dependent upon the availability of sodium. 2) The effect of an independent method for introducing more sodium into the transport pathway of the tissue (treatment with amphotericin B) was examined to see whether an increased entry of sodium per se could mimic the metabolic effects of the hormone. Striking metabolic effects associated with the hormonal action (7-10) have suggested that the stimulation of sodium transport by this hormone depends upon a channeling of metabolism to provide more energy for the active transport of sodium. The evidence for this alternative view will be examined.

\section{Methods}

Sodium transport across the toad bladder was measured as the short circuit current in double chambers, a technique that has been described in detail previously (1). With one half bladder mounted across a double chamber, one quarter serves as a test tissue and one as a control. When the spontaneous membrane potential 
is reduced to zero in the short circuited preparation, the electrical current required to maintain the potential at zero is equivalent to the sodium transport across the bladder. Toads used for these studies were maintained partially immersed in $0.6 \%$ saline solution for 24 to 48 hours before use to decrease the endogenous secretion of aldosterone. The amphibian-Ringer's solution used for experiments involving substrate utilization studies contained $\mathrm{Na}, 115 ; \mathrm{K}, 3.5 ; \mathrm{Cl}, 116.5 ; \mathrm{HCO}_{3}, 2.4 \mathrm{mEq}$ per $\mathrm{L}$; and $\mathrm{Ca}, 0.89$; and $\mathrm{PO}_{4}, 2$ mmoles per $\mathrm{L}$. The $\mathrm{pH}$ in air of the amphibian-Ringer's solution was 7.7 , and the total solute concentration was $230 \mathrm{mOsm}$ per $\mathrm{kg}$ water. For experiments requiring sodium-free Ringer's solution on the mucosal surface of the bladder, a solution was used that contained sucrose, $200 ; \mathrm{K}, 3.0 ; \mathrm{HCO}_{8}, 3.0 \mathrm{mEq}$ per $\mathrm{L}$; and $\mathrm{Ca}, 0.89$ mmole per $\mathrm{L}$; the total solute concentration was $230 \mathrm{mOsm}$ per $\mathrm{kg}$ water, and the $\mathrm{pH}$ in air was 7.8. When $d$-aldosterone was used, it was added in $5 \mu \mathrm{l}$ of methanol to the medium bathing the serosal surface of the tissue. Five $\mu l$ of methanol was added similarly to the control. Amphotericin B, when used, was added to the medium bathing the mucosal surface of the tissue.

The rate of utilization of acetoacetate and pyruvate, in the presence and absence of sodium in the mucosal bathing medium, was determined by experiments with the double chamber. The ${ }^{14} \mathrm{CO}_{2}$ released, from $1 \mathrm{mM}$ ethyl acetoacetate containing ethyl acetoacetate $-3-{ }^{14} \mathrm{C}$ or $1 \mathrm{mM}$ sodium pyruvate containing sodium pyruvate- $1-{ }^{14} \mathrm{C}$, by quarter bladders was determined as previously described $(9,10)$. Bladders were depleted of endogenous substrates before the determination of the rates of utilization by incubating in Ringer's solution. The ${ }^{14} \mathrm{CO}_{2}$ released was collected by passing all the air used to aerate and stir the medium through trains of three tubes, the first of which contained $1.0 \mathrm{ml}$ of $0.15 \% \mathrm{HCl}$ in $50 \%$ methanol to trap volatile substrates. The last two tubes in the train contained $1 \mathrm{ml}$ of $0.5 \mathrm{M}$ hydroxide of Hyamine in methanol. At the end of the incubation of the bladder with labeled acetoacetate or pyruvate the experiment was terminated by the injection of $0.2 \mathrm{ml}$ of $2 \mathrm{~N} \mathrm{H}_{2} \mathrm{SO}_{4}$ into the $5 \mathrm{ml}$ of Ringer's solution bathing each surface of the bladder. Aeration of the chambers was continued for a further 15 minutes to transfer all the ${ }^{14} \mathrm{CO}_{2}$ to the alkaline trap. Sodium transport was measured simultaneously with the utilization of substrate. The Hyamine solution containing the trapped ${ }^{14} \mathrm{CO}_{2}$, in the last two tubes of the train, was transferred quantitatively to a toluene scintillation mixture ( $p$-bis[2-(5-phenyloxazolyl)]-benzene (POPOP), $0.15 \mathrm{~g}$; 2,5-diphenyloxazole (PPO), $4.38 \mathrm{~g}$; toluene, $1 \mathrm{~L}$ ) with $5 \mathrm{ml}$ methanol and the radioactivity measured in a Packard Tri-Carb scintillation spectrometer. In some experiments the ${ }^{14} \mathrm{CO}_{2}$, after passing through the acid trap, was collected directly by passing it through the toluene-methanol scintillation fluid containing $0.5 \mathrm{ml}$ hydroxide of Hyamine in counting vials, thus eliminating the need for a quantitative transfer step. At the end of ${ }^{14} \mathrm{CO}_{2}$ collection, the tissues were carefully removed from the chambers and their dry weights determined. Volatility of the labeled substrate was determined under conditions of the experiment and the appropriate small blank subtracted from the radioactivity measured under experimental conditions. Penicillin G and streptomycin sulfate were added to the medium in concentrations of approximately $0.1 \mathrm{mg}$ per $\mathrm{ml}$ to inhibit bacterial utilization of substrates.

Determination of ATP, ADP, and phosphocreatine in the toad bladder was carried out under different conditions of hormonal treatment by the enzymatic methods detailed by Lowry, Passonneau, Hasselberger, and Schulz (11), including their strict conditions to avoid hydrolysis during the extraction of the tissue. In one series of experiments ATP was determined by the luciferase method (12). The nucleotides were referred to dry weight or DNA content of the tissue; DNA was determined colorimetrically with diphenylamine.

TABLE I

A. Effect of aldosterone on the utilization of pyruvate and acetoacetate in the absence of sodium in the mucosal medium*

\begin{tabular}{|c|c|c|c|c|c|}
\hline & \multirow[b]{2}{*}{$\mathbf{n}$} & \multicolumn{2}{|c|}{ Aldosterone } & \multirow[b]{2}{*}{$\Delta \pm$ SEM } & \multirow[b]{2}{*}{$\mathbf{p}$} \\
\hline & & Present & Absent & & \\
\hline $\begin{array}{l}\text { Pyruvate } \\
\text { Acetoacetate }\end{array}$ & $\begin{array}{r}9 \\
10\end{array}$ & $\begin{array}{l}0.046 \\
0.0057\end{array}$ & $\begin{array}{l}0.044 \\
0.0054\end{array}$ & $\begin{array}{l}0.002 \pm 0.004 \\
0.0003 \pm 0.0004\end{array}$ & $\begin{array}{l}0.7 \\
0.5\end{array}$ \\
\hline
\end{tabular}

B. Effect of addition of sodium to mucosal medium on the utilization of pyruvate and acetoacetate in the presence of aldosterone*

\begin{tabular}{|c|c|c|c|c|c|}
\hline & \multirow[b]{2}{*}{$\mathbf{n}$} & \multicolumn{2}{|c|}{ Sodium } & \multirow[b]{2}{*}{$\Delta \pm$ SEM } & \multirow[b]{2}{*}{ p } \\
\hline & & Present & $\overline{\text { Absent }}$ & & \\
\hline $\begin{array}{l}\text { Pyruvate } \\
\text { Acetoacetate }\end{array}$ & $\begin{array}{r}20 \\
8\end{array}$ & $\begin{array}{l}0.087 \\
0.029\end{array}$ & $\begin{array}{l}0.060 \\
0.020\end{array}$ & $\begin{array}{l}0.027 \pm 0.006 \\
0.009 \pm 0.002\end{array}$ & $\begin{array}{l}<0.001 \\
<0.01\end{array}$ \\
\hline
\end{tabular}

* Parts A and B were done at different times of the year; therefore no direct comparison between the actual values of substrate utilization is possible; differences in availability of endogenous substrates may be considerable under such circumstances.

Values are micromoles pyruvate-1-14 $\mathrm{C}$ decarboxylated or acetoacetate-3-14 $\mathrm{C}$ utilized per milligram dry weight per hour. $2 \times 10^{-7} \mathrm{M} d$-aldosterone was present in serosal medium of both paired tissues in part $\mathrm{B}$ and in medium of one tissue in part $A$. 


\section{Results}

Dependence on sodium of the increased utilization of substrate in the presence of aldosterone. It has been shown that in the presence of aldosterone, but not in its absence, pyruvate and acetoacetate stimulate sodium transport and that the increased sodium transport is associated with an increased rate of oxidation of these substrates (10). It thus became of interest to determine whether these changes in tissue metabolism are primary events or occur only secondary to the availability of sodium to be transported. The rate of pyruvate and acetoacetate oxidation, therefore, was determined in the presence and absence of sodium bathing the mucosal medium.

Part A, Table I, shows the results of experiments in which only one portion of tissue was exposed to aldosterone and no sodium was present in the mucosal medium of either tissue. The results indicate that aldosterone, in fact, had no effect in increasing the utilization of substrates in the absence of mucosal sodium. Part B, Table I, shows that the increased utilization of pyruvate and acetoacetate, characteristic of aldosterone (10), is dependent upon the presence of sodium in the mucosal bathing medium. In these experiments both portions of tissue were exposed to aldosterone 3 hours before the measurements of substrate utilization. Labeled pyruvate or acetoacetate was then

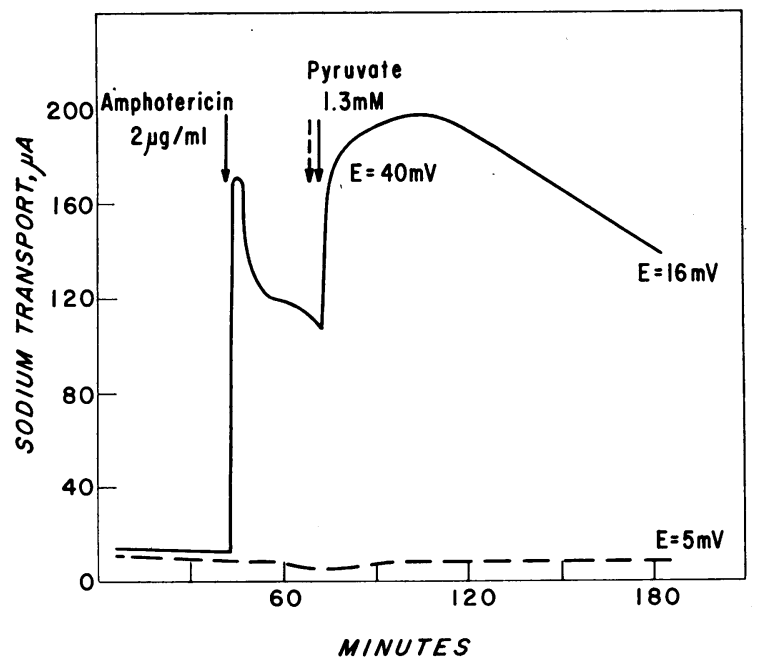

Fig. 1. The EFFeCt OF AMPHotericin B ON SODIUM TRANSPORT AND THE SUBSEQUENT RESPONSE TO PYRUVATE IN THE ABSENCE OF ALDOSTERone. The tissues were incubated in the absence of aldosterone for 12 hours before zero time. $\mathrm{E}=$ transbladder potential.

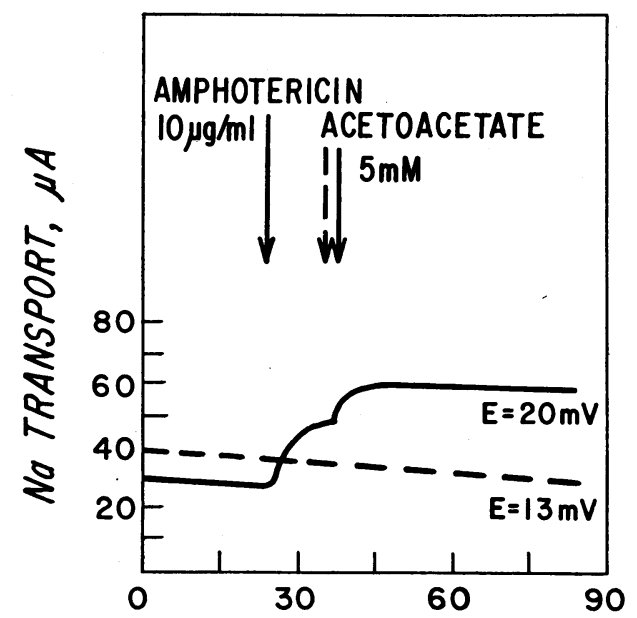

MINUTES

Fig. 2. THE EFFECT OF AMPHOTERICIN B ON SODIUM TRANSPORT AND THE SUBSEQUENT RESPONSE TO ACETOACETATE IN THE ABSENCE OF ALDOSTERONE. The tissues were incubated in the absence of aldosterone for 5 hours before zero time.

added to the bathing medium of both portions of tissue but sodium only to the mucosal medium of one. The absence of sodium prevented the increased utilization of both pyruvate and acetoacetate that is characteristic of the response to aldosterone.

Since the aldosterone was in contact with the tissues during a 3-hour period during which no sodium was present in the mucosal bathing medium of either portion of tissue, it was necessary to demonstrate that the hormone still exerted its usual action in preparing the tissue for an increased rate of sodium transport. This was examined in eight experiments in which the rates of sodium transport by paired tissues, one with and one without prior exposure to aldosterone, were compared in the first 30 minutes after adding sodium to the mucosal medium of each. The rate of sodium transport by the aldosterone-treated tissue was significantly greater than the control; 0.48 and $0.25 \mu \mathrm{Eq}$ of sodium transported per mg dry weight in the first 30 minutes after addition of sodium for the aldosterone-treated and control tissues, respectively $(\Delta \pm \mathrm{SEM}=0.23 \pm 0.047, \mathrm{p}<0.001)$. This indicates that aldosterone had prepared the tissue for an increased rate of sodium transport, even in the absence of sodium to be transported.

The dependence of the rate of substrate utiliza- 


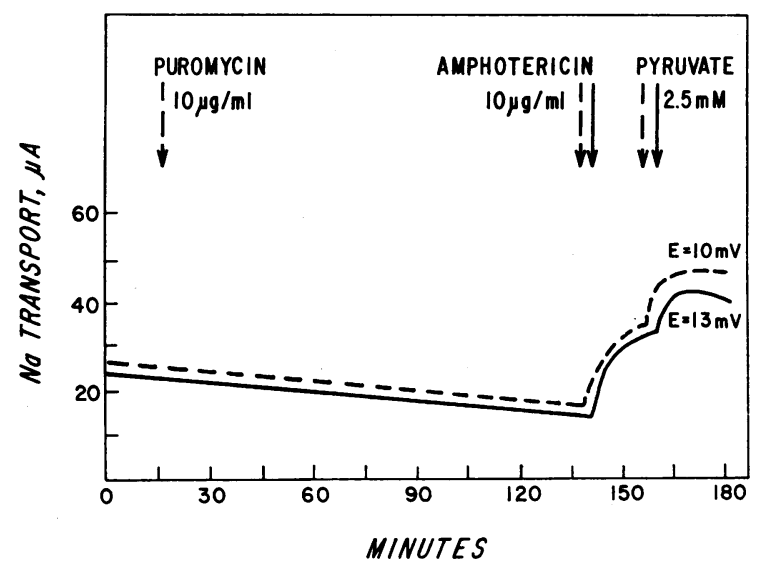

Fig. 3. The efFect OF AMPHOtericin B ON SODIUM TRANSPORT AND THE SUBSEQUENT RESPONSE TO PYRUVATE IN THE PRESENCE OF PUROMYCIN. The tissues were incubated in the absence of aldosterone for 4 hours before zero time.

tion upon the availability of sodium to be transported is in accord with the hypothesis that the basic action of aldosterone is to admit more sodium into the transport mechanism, thus bringing about increased substrate utilization.

The effect of amphotericin $B$ on the response of sodium transport to substrates. It has been shown previously that amphotericin $\mathrm{B}$, when added to the mucosal bathing medium, markedly augments sodium transport secondary to reducing the permeability barrier to that ion at the apical surface of the mucosal layer of cells (13). The response of tissues to substrates after exposure to amphotericin $\mathrm{B}$ but in the absence of aldosterone was, therefore, tested. Figure 1 shows the large increase in short circuit current and potential difference induced by amphotericin B. It also shows the secondary stimulation of sodium transport by pyru-

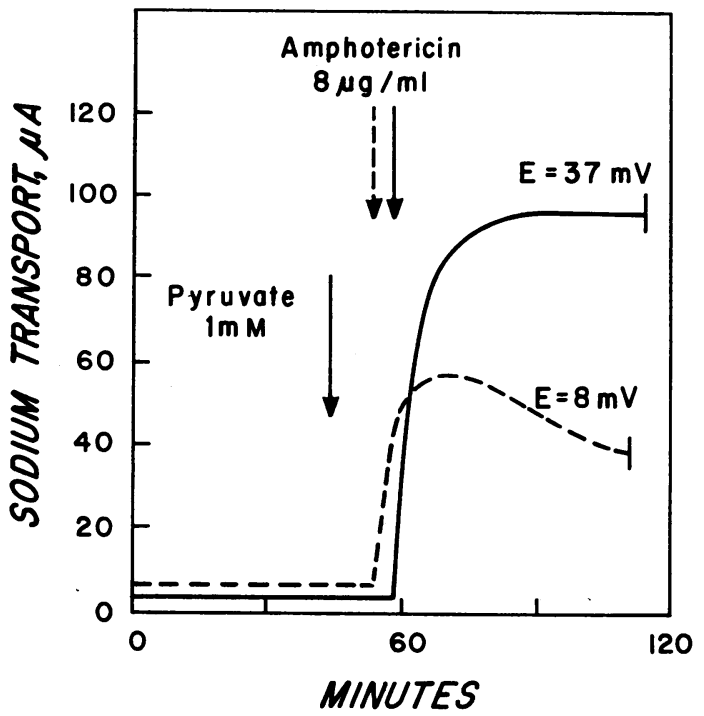

Fig. 4. The efFect OF SUbStrate ON SODIUM TRANSFORT STIMULATED BY AMPHOTERICIN B IN THE ABSENCE OF ALDOSTERONE. The tissues were incubated in the absence of aldosterone for 14 hours before zero time.

vate in the tissue treated with amphotericin $\mathrm{B}$ but the absence of any response to pyruvate in the control. Figure 2 shows similarly the effectiveness of acetoacetate in stimulating sodium transport in the tissue exposed to amphotericin B but the absence of an effect of this substrate in the control tissue not exposed to amphotericin B. In other experiments the effects of other substrates were tested, and the findings indicate that just those substrates which are effective in enhancing sodium transport in the presence of aldosterone, that is, glucose, pyruvate, oxaloacetate, lactate, and acetoacetate, are effective after amphotericin $B$. It can also be shown (Figure 3) that the effects of amphotericin $\mathrm{B}$ and the subsequent response to

TABLE II

The effects of amphotericin B on the utilization of pyruvate and acetoacetate and on transport of sodium in toad bladder

\begin{tabular}{|c|c|c|c|c|c|}
\hline & \multirow[b]{2}{*}{$\mathbf{n}$} & \multicolumn{2}{|c|}{ Amphotericin B } & \multirow[b]{2}{*}{$\Delta \pm \mathrm{SEM}$} & \multirow[b]{2}{*}{ p } \\
\hline & & Present & Absent & & \\
\hline $\begin{array}{c}\text { A. Pyruvate } \\
\text { Utilization* } \\
\text { Transport } \dagger\end{array}$ & $\begin{array}{l}10 \\
10\end{array}$ & $\begin{array}{l}0.101 \\
1.00\end{array}$ & $\begin{array}{l}0.078 \\
0.13\end{array}$ & $\begin{array}{l}0.023 \pm 0.008 \\
0.87 \pm 0.16\end{array}$ & $\begin{array}{l}<0.02 \\
<0.001\end{array}$ \\
\hline $\begin{array}{l}\text { B. Acetoacetate } \\
\text { Utilization* } \\
\text { Transport } \dagger\end{array}$ & $\begin{array}{l}9 \\
7\end{array}$ & $\begin{array}{l}0.012 \\
0.87\end{array}$ & $\begin{array}{l}0.005 \\
0.12\end{array}$ & $\begin{array}{l}0.006 \pm 0.002 \\
0.74 \pm 0.08\end{array}$ & $\begin{array}{l}<0.01 \\
<0.001\end{array}$ \\
\hline
\end{tabular}

* Micromoles per milligram dry weight per hour as measured by ${ }^{14} \mathrm{CO}_{2}$ release from pyruvate-1-14 $\mathrm{C}$ and acetoacetate$3-{ }^{14} \mathrm{C}$, respectively, during the first 30 minutes after addition of amphotericin $\mathrm{B}$.

$\dagger$ Microequivalents per milligram dry weight per hour measured simultaneously with the utilization of pyruvate or acetoacetate. 
TABLE III

Effects of aldosterone on concentrations of ATP, $A D P$, and creatine phosphate*

\begin{tabular}{lccccr}
\hline \hline & & $\begin{array}{c}\text { Aldos- } \\
\text { terone }\end{array}$ & Control & $\Delta \pm$ SEM & p \\
\hline A. & n & & & & \\
ATP & 16 & 0.027 & 0.034 & $-0.007 \pm 0.006$ & 0.3 \\
B. & & & & & \\
ATP & 12 & 0.42 & 0.38 & $0.04 \pm 0.02$ & $<0.2$ \\
ADP & 11 & 0.14 & 0.15 & $-0.01 \pm 0.02$ & 0.6 \\
Creatine P & 12 & 0.75 & 0.73 & $0.02 \pm 0.05$ & 0.7 \\
C. & & & & & \\
ATP & 12 & 0.51 & 0.52 & $-0.01 \pm 0.03$ & 0.7 \\
ADP & 12 & 0.15 & 0.13 & $0.02 \pm 0.01$ & $<0.1$ \\
Creatine P & 12 & 0.65 & 0.77 & $-0.12 \pm 0.08$ & $<0.2$ \\
D. & & & & & \\
ATP & 11 & 0.38 & 0.38 & $0.00 \pm 0.2$ & \\
Creatine P & 11 & 0.75 & 0.84 & $-0.09 \pm 0.08$ & 0.3 \\
Sodium transport & 11 & 60 & 13 & & \\
\hline & & Aldos- & & & \\
& & terone & & & \\
& & and & Aldos- & & \\
& $\mathrm{n}$ & ouabain & terone & $\Delta \pm$ SEM & $\mathrm{p}$ \\
\hline E. & & & & & \\
ATP & 7 & 0.44 & 0.48 & $-0.04 \pm 0.03$ & 0.2 \\
Creatine P & 7 & 0.85 & 0.92 & $-0.07 \pm 0.06$ & 0.3 \\
Sodium transport & 7 & 33 & 70 & & \\
\hline
\end{tabular}

\begin{tabular}{|c|c|c|c|c|c|}
\hline & $\mathbf{n}$ & $\begin{array}{l}\text { Aldos- } \\
\text { terone } \\
\text { and } \\
\text { ouabain }\end{array}$ & Control & $\Delta \pm \mathrm{SEM}$ & p \\
\hline \multicolumn{6}{|l|}{$F$} \\
\hline ATP & 8 & 0.41 & 0.42 & $-0.01 \pm 0.04$ & 0.8 \\
\hline Creatine $P$ & 8 & 0.78 & 0.84 & $-0.06 \pm 0.08$ & 0.5 \\
\hline Sodium transport & 8 & 46 & 18 & & \\
\hline
\end{tabular}

* Sodium transport expressed as mean current in microamperes just before analyses. ATP, ADP, and creatine phosphate expressed as micromoles per milligram DNA except for part A, which is expressed as micromoles per $100 \mathrm{mg}$ wet weight of tissue. A assayed for ATP by the luciferase method of Strehler and McElroy (12). B, C, D, E, and F assayed for ATP, ADP, and creatine phosphate by the method of Lowry and associates (11).

A Tissues incubated 5 hours with $d$-aldosterone $\left(1 \times 10^{-7} \mathrm{M}\right)$ to A. tissue initially, then pyruvate $(1.0 \mathrm{mM})$ to both for a final hour one tissue initially, then pyruvate $(1.0 \mathrm{mM}$ ) to both for a final hour of incubation. ATP assayed by

B. Tissues incubated 10 to 17 hours with $d$-aldosterone $\left(1 \times 10^{-7}\right.$ ) to one tissue initially.

C. Tissues incubated 17 to 24 hours with $d$-aldosterone $\left(1 \times 10^{-7} \mathrm{M}\right)$ to one tissue initially and pyruvate $(1.0 \mathrm{mM})$ to both during the final our.

D. Tissues incubated 10 to 14 hours in chamber with $d$-aldosterone $\left(2 \times 10^{-7} \mathrm{M}\right)$ to one tissue initially and pyruvate $(2.5 \mathrm{mM})$ to both during the final hour.

E. Tissues incubated 4 hours in chamber with $d$-aldosterone $\left(2 \times 10^{-1}\right.$ $M)$ and pyruvate $(1.0 \mathrm{mM})$ to both tissues and ouabain $\left(1 \times 10^{-5} \mathrm{M}\right)$ to one side at start of incubation.

F. Tissues incubated 4 to 7 hours in chamber with $d$-aldosterone $\left(2 \times 10^{-7} \mathrm{M}\right)$ to one before pyruvate $(1 \mathrm{mM})$ was added to serosal medium of both. At onset of response to pyruvate, ouabain $\left(1 \times 10^{-}\right.$ $M)$ was added to the tissue exposed to aldosterone and the experiment terminated 2 hours later.

substrate are unaffected by the presence of puromycin at a concentration that eliminates the response to aldosterone and substrates (14). Furthermore, in a series of nine experiments, pyruvate was added before the amphotericin $B$ in the absence of aldosterone. In all nine experiments higher rates of sodium transport were seen immediately upon addition of amphotericin $B$ in the tissues that received the substrate. The rapidity of this substrate effect can be seen in Figure 4. Table II documents that in the first 30 minutes after the addition of amphotericin $\mathrm{B}$ a significant increase occurs in the utilization of pyruvate and acetoacetate in association with the increased rate of sodium transport. Since amphotericin B admits increased amounts of sodium into the tissue across the apical surface and since this agent induces the same susceptibility of the tissue to subtrates as aldosterone, it is suggested that aldosterone, too, accomplishes its effect secondary to facilitating the entry of sodium into the tissue across the apical permeability barrier of the mucosal layer of cells.

The effect of aldosterone and substrates on the levels of ATP in toad bladder. Edelman and associates have supported the hypothesis that aldosterone acts by directing energy from metabolism into pathways for sodium transport by reporting that, in the presence of aldosterone, tissue levels of adenosine triphosphate in toad bladder are higher than in the absence of the hormone $(7,8)$. We have, therefore, examined the levels of ATP, ADP, and phosphocreatine in toad bladder under a variety of conditions in which hormonal and substrate effects have been elicited, as seen in Table III. In none of the conditions tested were we able to demonstrate differences in ATP content between the aldosterone-treated and control tissues.

\section{Discussion}

The transport of sodium across the toad bladder is currently visualized as occurring in the following manner (3): Sodium is thought to enter the active transport pool in the epithelial layer of cells by a process involving interaction with receptor sites at the apical surface of these cells. The driving force for entry of sodium into the transport pool is thought to be the electrochemical potential gradient for sodium across this surface. A transport mechanism located at the basal surface of these cells moves sodium from the transport pool to body fluids by a process coupled to the energy metabolism of the cells. Sodium, as well as metabolic intermediates, must serve as substrate for this active mechanism with the rate of transport accelerated by an increase in sodium in the transport pool of the cells. By analogy with enzymesubstrate reactions generally, an increased rate of 
sodium transport could in theory result from an increased delivery of sodium from mucosal medium into the cells with no change in the amount of enzymatic machinery or from an increase in the machinery.

The evidence presented here indicates the sufficiency of an action of aldosterone to stimulate sodium transport by enhancing the entry of sodium into the transport pool through the mucosal surface of the epithelial cells $(1,15,16)$. Without an increase in its enzymatic components the active transport system has adequate capacity, in the absence of aldosterone, to accommodate the hormonal stimulation of sodium transport.

It has been shown that the action of aldosterone on the toad bladder is associated with an increased rate of aerobic metabolism (10). This finding has allowed us to show that the metabolic effects of aldosterone are entirely dependent upon the presence of sodium in the mucosal bathing medium. This is in accord with the hypothesis that the hormonal action is to admit more sodium to the transport mechanism but is not by itself conclusive. Conceivably, a primary action of the hormone to provide energy for sodium transport could result in a small increase in available energy not detectable by present techniques. Without sodium to be transported, this increase in the supply of energy for sodium transport might not be dissipated and might prevent any further increase in energy metabolism. Thus a similar dependence of the metabolic activity on the availability of sodium might appear irrespective of the primary action of the hormone in experiments such as these.

If it can be shown that increased sodium entry alone can stimulate sodium transport and induce the metabolic effects characteristic of the hormone, then there is no logical need to postulate an action of the hormone other than that on the entry of sodium. It has been shown that the action of aldosterone is associated with characteristic substrate requirements $(10,17)$. Thus in the presence of aldosterone, but not in its absence, sodium transport in the toad bladder is supported by pyruvate and its precursors (glucose, lactate, and oxaloacetate) and by acetoacetate and $\beta$-hydroxybutyrate. It is not supported by intermediates of the tricarboxylic acid cycle such as $\alpha$-ketoglutarate or succinate. In addition, the action of aldosterone is associated with a significant increase in the rate of utilization of pyruvate and acetoacetate. It has also been shown that amphotericin $B$, when added to the mucosal bathing medium, markedly augments sodium transport secondary to reducing the permeability barrier to that ion at the apical surface of the mucosal layer of cells (13). The present study demonstrates that this action of amphotericin B on sodium transport in fact induces all the observed effects of aldosterone on metabolism. Thus amphotericin B in the absence of aldosterone makes the bladder responsive to just those substrates to which the tissue is sensitive after aldosterone. Furthermore, the increased rate of transport induced by amphotericin B is associated with an increased rate of utilization of pyruvate and acetoacetate. These effects, which are observed promptly after amphotericin $\mathrm{B}$, and even in the presence of puromycin, exclude any requirement for the synthesis of enzymes concerned with energy metabolism.

Although the present study demonstrates that an action on sodium entry would be sufficient to account for the hormonal effect, it does not exclude other possibilities. Since an action to channel more metabolic energy into the transport process has been suggested, it is pertinent to examine the consequences of such an action. For any given permeability of the apical surface of the mucosal cells to sodium, the electrochemical gradient will determine its entry into the transport pathway. This being the case, the concentration of sodium in the pathway must normally be kept very low, or the cell interior must be electrically negative to the mucosal medium, since active transport at this cell surface seems excluded (18). Measurements of the active sodium transport pool indicate that it diminishes in size with reduction of concentration of sodium in the mucosal medium even to concentrations less than $1 \mathrm{mEq}$ per $\mathrm{L}$ (2). Furthermore, measurements of the electrical potential gradient across this surface indicate that the cell interior is positive with respect to the mucosal medium even when the concentration of sodium in the medium is reduced. Without active transport of sodium at the mucosal surface the low values for the amount of sodium in the transport pathway must mean a concomitant low concentration of sodium in the pathway. Thus any mechanism that stimulated transepithelial transport solely by increasing the removal of sodium across the basal 
surface would be ineffective and incapable of the two- to threefold augmentation of the rate of sodium transport commonly observed with aldosterone. This is a limitation imposed by the fact that a further drop in concentration of sodium within a pool that already has a low concentration can contribute only a small percentage increase in the gradient for sodium entry across the mucosal surface and hence in the rate of transepithelial movement of sodium.

Neurohypophysial hormones have previously been shown to enhance sodium transport also by augmenting entry of sodium into the epithelium through its mucosal surface (2). However, unlike the situation after amphotericin B, after vasopressin no clear-cut response to substrates was demonstrated. For this and other reasons, we have concluded that vasopressin affects pathways for entry of sodium that are separate and parallel to those affected by aldosterone (14).

In conclusion, we suggest that aldosterone acts to enhance the entry of sodium into the transport system. The entry of sodium through the apical surface is usually rate limiting and the content of sodium in the active transport pool kept at low concentrations by efficient active extrusion of sodium across the serosal surface of the cells. Increased entry of sodium results in increased sodium transport. If aldosterone acts via synthesis of a specific protein, in accord with the hypothesis of Williamson (19) and of Edelman, Bogoroch, and Porter $(17,20)$, then this protein will be analogous to the permeases of bacterial systems. This is an example of regulation of sodium transport by modification of the special apical surface on which the oriented transepithelial transport of sodium depends.

\section{Summary}

Studies on the mode of action of aldosterone have been carried out with the isolated bladder of the toad, Bufo marinus. The increased rate of aerobic metabolism that is associated with the stimulation of sodium transport by aldosterone is dependent upon the presence of sodium in the mucosal bathing medium. Amphotericin B, which increases sodium transport by reducing the permeability barrier to sodium at the apical surface, has been shown to mimic the metabolic effects of aldosterone in this tissue.
The evidence demonstrates the adequacy of the hypothesis that the action of aldosterone is to increase the entry of sodium into the transport pathway across the apical surfaces of the mucosal epithelial cells. It is suggested that the metabolic effects of aldosterone are secondary to the entry of sodium into the tissue.

\section{Acknowledgments}

The authors wish to express their thanks to Miss Eleanor F. Dempsey for carrying out the assays of ATP, ADP, and creatine phosphate, and to Mrs. Constance L. Komack for technical assistance. We are grateful to Dr. Maurice M. Pechet for supplies of $d$-aldosterone.

\section{References}

1. Sharp, G. W. G., and A. Leaf. Biological action of aldosterone in vitro. Nature (Lond.) 1964, 202, 1185.

2. Frazier, H. S., E. F. Dempsey, and A. Leaf. Movement of sodium across the mucosal surface of the isolated toad bladder and its modification by vasopressin. J. gen. Physiol. 1962, 45, 529.

3. Leaf, A. Transepithelial transport and its hormonal control in the toad bladder. Ergebn. Physiol. 1965, 56, 216.

4. Essig, A. Active sodium transport in the toad bladder despite removal of serosal potassium. Amer. J. Physiol. 1965, 208, 401.

5. Frazier, H. S., and A. Leaf. The electrical characteristics of active sodium transport in the toad bladder. J. gen. Physiol. 1963, 46, 491.

6. Choi, J. K. The fine structure of the urinary bladder of the toad, Bufo marinus. J. Cell Biol. 1963, 16, 53.

7. Edelman, I. S. Mechanism of action of aldosterone. Proceedings of the Second International Congress on Endocrinology, Excerpta Medica International Congress Series. London, Excerpta Medica Foundation, 1965, part I, p. 60.

8. Edelman, I. S., R. Bogoroch, and G. A. Porter. Specific action of aldosterone on RNA synthesis. Trans. Ass. Amer. Phycns 1964, 77, 307.

9. Sharp, G. W. G., N. S. Lichtenstein, and A. Leaf. Acetyl coenzyme A requirement for the stimulation of sodium transport by aldosterone. Biochim. biophys. Acta (Amst.) 1965, 111, 329.

10. Sharp, G. W. G., and A. Leaf. Metabolic requirements for active sodium transport stimulated by aldosterone. J. biol. Chem. 1965, 240, 4816.

11. Lowry, O. H., J. V. Passonneau, F. X. Hasselberger, and D. W. Schulz. Effect of ischemia on known substrates and cofactors of the glycolytic pathway in brain. J. biol. Chem. 1964, 239, 18.

12. Strehler, B. L., and W. D. McElroy. Assay of adenosine triphosphate in Methods in Enzymology, 
S. P. Colowick and N. O. Kaplan, Eds. New York, Academic Press, 1957, vol. 3, p. 871.

13. Lichtenstein, N. S., and A. Leaf. Effect of amphotericin $\mathrm{B}$ on the permeability of the toad bladder. J. clin. Invest. 1965, 44, 1328.

14. Sharp, G. W. G., and A. Leaf. Studies on the mode of action of aldosterone. Recent Progr. Hormone Res. 1966, 22, in press.

15. Sharp, G. W. G., and A. Leaf. Studies on the biological action of aldosterone in vitro (abstract). J. clin. Invest. 1963, 42, 978.

16. Crabbé, J., and P. De Weer. Action of aldosterone and vasopressin on the active transport of sodium by the isolated toad bladder. J. Physiol. (Lond.) $1965,180,560$.
17. Edelman, I. S., R. Bogoroch, and G. A. Porter. On the mechanism of action of aldosterone on sodium transport; the role of protein synthesis. Proc. nat. Acad. Sci. (Wash.) 1963, 50, 1169.

18. Civan, M. M., O. Kedem, and A. Leaf. Effect of vasopressin on toad bladder under conditions of zero net sodium transport. Amer. J. Physiol. 1966, in press.

19. Williamson, H. E. Mechanism of the antinatriuretic action of aldosterone. Biochem. Pharmacol. 1963, $12,1449$.

20. Porter, G. A., R. Bogoroch, and I. S. Edelman. On the mechanism of action of aldosterone on sodium transport: the role of RNA synthesis. Proc. nat. Acad. Sci. (Wash.) 1964, 52, 1326. 